\title{
In vitro growth of Oncidium sphacelatum (Orchidaceae) in different concentrations of sucrose and nutrients
}

\section{Crecimiento in vitro de Oncidium sphacelatum (Orchidaceae) en diferentes concentraciones de sacarosa y nutrientes}

\author{
NAVARRETE-VALENCIA, Ana Luisa $\dagger^{*}$, RAMÍREZ-GUERRERO, Leobarda Guadalupe, \\ SÁNCHEZ-MONTEÓN Ana Luisa and JIMÉNEZ-MEZA, Víctor Manuel
}

\section{Universidad Autónoma de Nayarit, Unidad Académica de Agricultura}

ID $1^{\text {st }}$ Author: Ana Luisa, Navarrete-Valencia / ORC ID: 0000-0003-2976-7275

ID $1^{\text {st }}$ Coauthor: Leobarda Guadalupe, Ramírez-Guerrero / ORC ID: 0000-0003-1764-477X, Research ID Thomson: S7947-2018, CVU CONACYT ID: 211448

ID $2^{\text {nd }}$ Coauthor: Ana Luisa, Sánchez-Monteón / ORC ID: 0000-0003-3781-2400, CVU CONACYT ID: 44857
ID $3^{\text {rd }}$ Coauthor: Víctor Manuel, Jiménez-Meza / ORC ID: 0000-0002-6925-9809, CVU CONACYT ID: 160315

DOI: $10.35429 / J E S N .2019 .16 .5 .30 .35$

Received June 26, 2019; Accepted December 30, 2019

\begin{abstract}
The objective of the present work was to offer an in vitro propagation alternative for the Oncidium sphacelatum orchid through the evaluation of the response to the crop in different concentrations of sucrose and the nutrient medium of Murashige and Skoog. Initially the seeds were sown in this culture medium at $100 \%$ of their concentration with the addition of $3.0 \%$ sucrose, once formed the protocorms the response to the application of different sucrose concentrations was evaluated $(3.0,2.25,1.5,0.75$ and $0 \%)$ and of the nutrients of the culture medium $(100,75,50,25$ and $0 \%$ ) under a completely randomized experimental design of eight treatments with four repetitions. The analysis of variance showed statistical differences between treatments for the formation of buds in the protocorms, number of leaves per bud, plant height, root length and formation of pseudobulbs in the shoots. The highest outbreak formation in the protoorms was observed in treatments with $3.0 \%$ sucrose and nutrient concentrations at 50 or $25 \%$. For the growth of the leaves and the root the concentration of $3.0 \%$ of sucrose was required combined with the concentrations of nutrients at 25,50 and $100 \%$. The formation of pseudobulbs in the outbreaks only occurred in the treatment with $3.0 \%$ sucrose combined with the $25 \%$ nutrient concentration.
\end{abstract}

Orchid, in vitro nutrition, Sucrose

\begin{abstract}
Resumen
El objetivo del presente trabajo tuvo por finalidad ofrecer una alternativa de propagación in vitro para la orquídea Oncidium sphacelatum por medio de la evaluación de la respuesta al cultivo en diferentes concentraciones de sacarosa y del medio nutritivo de Murashige y Skoog. Inicialmente las semillas se sembraron en este medio de cultivo al $100 \%$ de su concentración con la adición de 3.0\% de sacarosa, una vez formados los protocormos se evaluó la respuesta a la aplicación de diferentes concentraciones de sacarosa $(3.0,2.25,1.5,0.75$ y $0 \%)$ y de los nutrientes del medio de cultivo $(100,75,50,25$ y $0 \%)$ bajo un diseño experimental completamente al azar de ocho tratamientos con cuatro repeticiones. El análisis de varianza mostró diferencias estadísticas entre tratamientos para la formación de brotes en los protocormos, número de hojas por brote, altura de planta, longitud de raíz y formación de pseudobulbos en los brotes. La mayor formación de brotes en los protocormos se observó en los tratamientos con $3.0 \%$ de sacarosa y concentraciones de nutrientes al 50 ó $25 \%$. Para el crecimiento de las hojas y la raíz se requirió la concentración de $3.0 \%$ de sacarosa combinada con las concentraciones de nutrientes al 25,50 y $100 \%$. La formación de pseudobulbos en los brotes sólo se presentó en el tratamiento con $3.0 \%$ de sacarosa combinada con la concentración de nutrientes al $25 \%$.
\end{abstract}

Orquídea, nutrición in vitro, Sacarosa

Citation: NAVARRETE-VALENCIA, Ana Luisa, RAMÍREZ-GUERRERO, Leobarda Guadalupe, SÁNCHEZMONTEÓN Ana Luisa and JIMÉNEZ-MEZA, Víctor Manuel. In vitro growth of Oncidium sphacelatum (Orchidaceae) in different concentrations of sucrose and nutrients. Journal of Environmental Sciences and Natural Resources. 2019, 5-16: 3035

$\uparrow$ Researcher contributing first author. 


\section{Introduction}

The Orchidaceae family is one of the largest families in the plant kingdom, worldwide between 25,000 and 30,000 species are reported, represented with more than 725 genera (Dressler, 1981). In Mexico it is estimated that there are about 1,200 species, of which $40 \%$ are endemic. Likewise, it is one of the families with the highest number of species in extinction and one of the most monitored within CITES (Miceli et al., 2009).

\section{Justification}

Orchid seeds are among the smallest in the plant kingdom, basically they consist of an embryo and the testa, lacking a nutrient reserve (Arditti and Abdul-Ghani, 2000). Therefore, for their germination they require an obligatory symbiotic relationship with mycorrhizal fungi of the Rhizoctonia genus (Hadley, 1997; Suárez et al., 2006; Valadares et al., 2013). In orchids, the germination process begins when the seed is hydrated and turns green, resulting in an undifferentiated tissue called a protoorm, from which the seedling originates after going through five stages of development (Seaton and Ramsay, 2005): (1) formation of protoorm, (2) appearance of rhizoids, (3) appearance of apical meristem, (4) development of the first leaf and (5) appearance of the first root. From stage 5, the seedling is considered to be formed. Knowing the in vitro germination process of orchid seeds is essential to improve the propagation protocols for these species (Bertolini et al., 2016).

\section{Problem}

Under conditions of in vitro culture, the composition of the culture medium for the germination of the seeds and the growth of the plants is very important, being generally constituted by macro and micronutrients, vitamins, amino acids, sucrose and a gelling agent (Sorace et al. , 2008). The nutritious medium of Murashige and Skoog (1962) has been used successfully in the in vitro culture of orchids (Billard et al., 2014). In works carried out with the Laelia cinnabarina orchid, satisfactory results have been obtained when using this nutrient medium at half of its concentration (Stancato and Feria, 1996) or a third of its concentration with orchids of the genus Phalaenopsis (Bressan, et al., 1999).
In Oncidium baueri, treatment with 40 $\mathrm{gL}^{-1}$ of sucrose at half the concentration of the MS medium was the most efficient for vegetative growth and rooting (Sorace et al., 2008). According to Debegh (1991), sucrose is an important component as a source of carbon and energy. The experiments with the Diuris longifolia orchid showed increases in rooting by increasing the concentration of sucrose from 20 to $40 \mathrm{gL}^{-1}$.

In this research work, the Oncidium sphacelatum Lindley orchid was selected, it is an epiphytic or lithophyte species, which usually forms colonies, its foliage is lush and colorful, blooms from January to April, the inflorescence reaches up to $1.5 \mathrm{~m}$ long With numerous small and slightly fragrant flowers, yellow with reddish brown spots in the middle basal part, it is distributed in Mexico, Belize, Guatemala, El Salvador, Honduras and Venezuela (Miceli et al., 2009; Alayón, 2011).

According to Mc. Vaugh (1985) develops in the oak and pine-oak forests from 550 to $1700 \mathrm{~m}$ in the states of Jalisco, Nayarit and Sinaloa; this author reported abundance of this species in the surroundings of Compostela in the state of Nayarit.

\section{Objective}

The objective of the present work was to offer an in vitro propagation alternative for the Oncidium sphacelatum Lindley orchid by evaluating the response to the crop in different concentrations of sucrose and the nutrient medium of Murashige and Skoog.

\section{Methodology to be developed}

The experimental work was carried out in the Tissue Cultivation Laboratory of the Academic Unit of Agriculture 'of the Autonomous University of Nayarit'.

82-day-old plants (in a protoormal state) of an average size of two to three millimeters in diameter were used, which were obtained from mature seeds germinated in vitro asymptotically, in the MS culture medium (Murashige and Skoog, 1962). 
This medium was supplemented with 30 $\mathrm{gL}^{-1}$ sucrose, $8 \mathrm{gL}^{-1}$ agar, $100 \mathrm{mgL}-1$ myoinositol, $0.5 \mathrm{mgL}^{-1}$ nicotinic acid, $0.5 \mathrm{mgL}^{-}$ ${ }^{1}$ pyridoxine and $0.5 \mathrm{mgL}^{-1}$ thiamine, the $\mathrm{pH}$ was adjusted to 5.7 with $0.1 \mathrm{~N} \mathrm{KOH}$. The culture medium was sterilized in an autoclave at $121^{\circ} \mathrm{C}$ and $1 \mathrm{~kg} \mathrm{~cm} 2$ of pressure for 15 minutes and was distributed in $25 \mathrm{~mL}$ quantities in glass bottles of $120 \mathrm{~mL}$ capacity.

The sowing and disinfection of the capsule containing the seeds was carried out in the horizontal laminar flow hood, placed in a $1.2 \%$ sodium hypochlorite solution for ten minutes, then three rinses were applied with sterile water, then the capsule was placed on a sterile paper napkin to absorb the surrounding water and make a cross-section to distribute the seeds on the surface of the jars with culture medium, which were covered with two layers of transparent plastic film and fastened with a league of rubber to be taken to the incubation area.

During all phases of the in vitro culture from seed to the formation of whole plants in the incubation area the temperature was maintained from 23 to $30^{\circ} \mathrm{C}$, under a photoperiod of 16 hours, and were illuminated with fluorescent light lamps that provided a luminous intensity of $66 \mathrm{Wm}^{-2}$.

The seeds turned green from 20 days after sowing. To maintain the supply of water and nutrients, they were transferred to fresh medium with the same composition after 40 days of cultivation. The green seeds developed to the protoorm phase from 60 days after sowing, so the next change to fresh medium under different concentrations of sucrose and nutritive medium was planned.

\section{Experimental design and experimental unit}

A completely randomized experimental design with four repetitions was used, the treatments are shown in Table 1.

The experimental unit was formed by a flask containing a group of 20 plants (in a state of proto-form of a size of 2 to $3 \mathrm{~mm}$ in diameter).

\begin{tabular}{|l|l|}
\hline Treatment & \multicolumn{1}{c|}{ Composition } \\
\hline T-1 & distilled water gelled with agar \\
\hline T-2 & 25\% MS with 7.5 gL-1 sucrose \\
\hline T-3 & 50\% MS with 15 gL-1 sucrose, \\
\hline T-4 & 75\% MS with 22.5 gL-1 sucrose \\
\hline T-5 & 100\% MS with 30 gL-1 sucrose, \\
\hline T-6 & 75\% MS with 30 gL-1 sucrose, \\
\hline T-7 & 50\% MS with 30 gL-1 sucrose \\
\hline T-8 & 25\% MS with 30 gL-1 sucrose \\
\hline
\end{tabular}

Table 1 Treatments under evaluation

\section{Variables under study}

The variables studied at 115 days of culture in these treatments were the following:

\section{Survival of protoorms or shoots}

The count of protoorms or protoorms with vegetative bud formation that showed green color in its different shades was performed and calculated in percentage with respect to the initial number of 20 protoorms per experimental unit.

\section{Number of shoots}

The number of protoorms with bud formation per experimental unit was counted.

\section{Number of leaves per bud}

The number of leaves in the shoots per experimental unit was counted and subsequently the average number of leaves per shoot was obtained for statistical analysis.

\section{Plant height}

The plant height was determined by using a ruler and the unit of mediation established was in millimeters $(\mathrm{mm})$. This was determined from the base to the apex of the youngest leaf in the shoots per experimental unit and subsequently the average height was obtained for statistical analysis.

\section{Root length}

The root length was determined by the use of a ruler and the unit of mediation established was in millimeters $(\mathrm{mm})$. This was determined from the base to the apex of the root of greater length in the shoots per experimental unit and subsequently the average length was obtained for statistical analysis. 


\section{Pseudobulb formation}

The number of protoorms with bud formation and pseudobulb per experimental unit was counted.

\section{Statistic analysis}

The data obtained from the variables for each of the treatments were evaluated using an analysis of variance. For the variables number of shoots and number of leaves per bud, data transformation was performed using the square root of the value of $x+0.05$.

A means comparison test was also carried out according to the Tukey test $(\alpha=$ 0.05) with the support of EXCEL® statistical tools.

\section{Results}

After 197 days of in vitro culture, 100\% survival of both protoorms and outbreaks was observed in all treatments under evaluation.

The analysis of variance for the variables number of shoots, number of leaves per bud, plant height and root length showed highly significant statistical differences ( $\mathrm{P}$ $<0.01$ ) between treatments (Tables 2 and 3).

For the variable number of outbreaks, the Tukey test identified three groups, treatments with the concentration of 50 and $25 \%$ of nutrient medium and $30 \mathrm{gL}^{-1}$ of sucrose developed the largest number of outbreaks and formed the first group, the second was formed by treatments with 75 and $100 \%$ nutrient medium with $30 \mathrm{gL}^{-1}$ of sucrose and the third group is composed of treatments with the lowest concentrations of sucrose.

Similarly, Sorace et al., 2008 evaluated the number of Oncidium Bauer outbreaks and obtained the best results with the most dilute levels of the MS medium with 40 gL-1 sucrose.

\begin{tabular}{|c|c|c|c|}
\hline Treatment & \multicolumn{2}{|c|}{$\begin{array}{c}\text { Number of shoots } \\
*\end{array}$} & $\begin{array}{c}\text { Number of leaves per bud } \\
*\end{array}$ \\
\hline $\mathrm{T}-1$ & $3.11 \mathrm{c}$ & & 1.58 \\
\hline $\mathrm{T}-2$ & $3.38 \mathrm{c}$ & & $1.96 \mathrm{a}$ \\
\hline $\mathrm{T}-3$ & 3.35 & $\mathrm{c}$ & $1.99 \mathrm{a}$ \\
\hline $\mathrm{T}-4$ & 3.35 & c & $2.12 \mathrm{a}$ \\
\hline $\mathrm{T}-5$ & 3.99 & $\mathrm{~b}$ & $1.87 \mathrm{a} \mathrm{b}$ \\
\hline T-6 & 3.91 & b & 1.58 \\
\hline $\mathrm{T}-7$ & $4.52 \mathrm{a}$ & & $1.72 \quad b$ \\
\hline $\mathrm{T}-8$ & $4.52 \mathrm{a}$ & & $1.72 \quad b$ \\
\hline
\end{tabular}

Table 2. Test of multiple comparisons of means by the Tukey method $(\alpha=0.05)$ for the number of shoots and the number of leaves per shoot. * Means with the same letter are statistically equal.

\begin{tabular}{|c|c|c|}
\hline Treatment & $\begin{array}{c}\text { Plant height } \\
(\mathrm{mm})\end{array}$ & $\begin{array}{l}\text { Root Length } \\
(\mathrm{mm})\end{array}$ \\
\hline $\mathrm{T}-1$ & 7.25 & 0.00 \\
\hline $\mathrm{T}-2$ & $10.00 \quad b$ & $2.00 \quad c \quad c c d$ \\
\hline $\mathrm{T}-3$ & $10.75 \quad b$ & 2.75 \\
\hline $\mathrm{T}-4$ & $13.00 \quad b$ & 4.25 \\
\hline $\mathrm{T}-5$ & $17.75 \mathrm{a}$ & $12.00 \mathrm{a}$ \\
\hline T-6 & 9.00 & 13.75 \\
\hline $\mathrm{T}-7$ & $15.00 \mathrm{a}$ & $8.00 \quad b$ \\
\hline $\mathrm{T}-8$ & $15.00 \mathrm{a}$ & $10.00 \mathrm{a} \mathrm{b}$ \\
\hline
\end{tabular}

Table 3. Test of multiple comparisons of means by the Tukey method $(\alpha=0.05)$ for plant height and root length. * Means with the same letter are statistically equal.

For the variable plant height, the treatments with the lowest concentration of nutritive medium and $30 \mathrm{gL}-1$ of sucrose, Fraguas et al., 2003, obtained satisfactory growth of plants resulting from the cross between the Cattleya labiata and Laelia itambana orchids, in between MS culture with $20 \mathrm{gL}^{-1}$ sucrose.

For the variable number of leaves per bud, treatments T4, T2 and T5 stand out with the highest response to this variable.

For root length, treatment $\mathrm{T} 5$ and $\mathrm{T} 8$ showed a greater response, they coincide in the contribution of $30 \mathrm{gL}^{-1}$ of sucrose but differ in the concentration of the nutrient medium.

Del Rosario and De Guzmán (1981) obtained a positive effect promoted by the high concentration of sugar, in rooting embryos of coqueiro "makapuno" using nutritious medium MS. 
The results of the growth behavior of Oncidium baueri root show that there were no differences for the concentration of sucrose, but the treatment containing the MS medium at $1 / 2$ with the addition of $40 \mathrm{gL}^{-1}$ sucrose presented the greatest number of roots, and is statistically different from the concentration of $30 \mathrm{gL}^{-1}$, do not report statistical differences between the concentrations of 30 and $60 \mathrm{gL}^{-1}$ and differ statistically with the concentration of $40 \mathrm{gL}^{-1}$.

According to Oliveira (1994), high sugar concentrations can inhibit root formation in vitro.

The only treatment where pseudobulb formation was observed was T8 (25\% MS with $30 \mathrm{gL}-1$ sucrose) which has facilitated the process of acclimatization to the outside environment of the Oncidium sphacelatum orchid.

\section{Conclusions}

The growth of protoorms and the development of buds with leaves, roots and pseudobulbs of the Oncidium sphacelatum Lindley orchid was achieved with the supplement to the culture medium of $30 \mathrm{gL}-1$ sucrose.

The growth of protoorms and the development of shoots with leaves, roots and pseudobulbs was achieved with the contribution of nutrients to the culture medium of Murashige and Skoog (1962) at 25\% of the original concentration, this implies the decrease in cost and a reagent use savings.

The results obtained indicate that the sucrose supplement is essential for the orchid under study for normal growth and development of plants under artificial cultivation conditions. With respect to the contribution of mineral nutrients, the decrease of these in the nutritive environment is not affected, while maintaining the contribution of the energy source with the sucrose supplement.

\section{Acknowledgments}

The experimental work was supported by the Agronomist Engineer Aldo Gabriel Tejeda Cervantes, with the contribution of the capsules with the seeds of the species Oncidium sphacelatum Lindley and his experience in cultivation both under natural and in vitro conditions of these species. Likewise, the support in the activities of preparation of solutions, means of cultivation and sterilization of the Agronomist Silvia Ayala Castillo, both, members of the administrative staff of the Academic Unit of Agriculture. The Autonomous University of Nayarit is thanked for giving the working conditions that allowed the development of this research.

\section{References}

Alayón, G.J.A.(2011). Orquídeas en huertos familiares de Calakmul Campeche, México. Ecosur. Campeche, México.135 pp.

Arditti. J. \& A Abdul-Ghani, A.K. (2000). Transley Review No. 110. Numerical and physical properties of orchid seeds and their biological implications. New Phytol, 145(1),367 - 421. Doi:10.1046/j.14698137.2000.00587.x

Bertolini, V. Valle, M.J.R. y Rojas V.A.N. (2016).Aplicación de visión por computadora en la evaluación del desarrollo in vitro de protocormos de Oncidium sphacelatum Lindl., (Orchidaceae). Acta Agron. 65(3), 261267.doi:htpp://dx.doi.org/10.15446/acag.v65n3. 52212.

Billard, C.E., Dalzotto, C.A. y Lallana, V.H. (2014). Desinfección y siembra asimbiótica de semillas de dos especies y una variedad de orquídeas del género Oncidium. Polibotánica $38: 145-157$.

Del Rosario, A.G., Guzman, E.V. The growth of Makapuno coconut embryos in vitro as affected by mineral composition and sugar level of the médium during the liquid and solid culture. Philippine Journald of Cience. Manila. 105:215-222.

Debergh, P.C. (1991). Control of in vitro plant propagation. In: Crocomo, O.J., Sharp, W.R. (Ed.). Biotecnologia para producao vegetal. Piracicaba. CebTEC/FEALQ. 
Dressler, R.L. 1981. The Orchids. Nature Hystory and Classification. Harvard University Press, Cambridge.

Fraguas, C.B.,Villa, F., Souza, A.V.,Pasqual, M.,Dutra, L,F. (2003). Crescimiento in vitro de plántulas de orquídeas oriundas de hídricos, entre Cattleya labiata e Laelia itambana. Ceres, Lavras. V.50(292): 719-726.

Hadley, G.(1997). Orchid mycorrhiza. En Arditti, J y Pridgeon, A.M. (Eds.) Orchid Biology:Reviews and Perspectives vol 2. Cornell University Press. Ithaca, Nueva York. $83-118$ p.

Mc Vaugh, R. (1985). Flora Novo-Galiciana a descriptive account of the vascular plants of Western Mexico. W.I. Anderson (Ed.) The University of Michigan Press. Vol 16. 363 pp.

Miceli, M.C.L., C. Orantes G. y R. Pérez L. 2009. Orquídeas y bromelias del Parque Nacional Cañón del Sumidero. Universidad de Ciencias y Artes de Chiapas.Tuxtla Gutiérrez, Chiapas.155p.

Murashige, T. y F. Skoog. 1962. A revised médium for rapid growth and bioassays with tobacco tissue culture. Phy.Plant. 15:473-497.

Oliveira, P.D. (1994) Propagacao in vitro de crisantemo (Dedanthema grandiflora Tzlev cv Orange Reagen Lavras: 34-35.

Seaton, P.T. \& Ramsay, M. (2005). Growing orchid seed. Royal Botanic Gardens Kew, London. $128 \mathrm{p}$.

Sorace, M.,Tadeu, F.R., Damasceno J.C.V., Gomes, G.P., Muñiz B.C., Nesello V.F.G., Lopes, S.G., Assari, T.L.S., Schnitzer, J.A. (2008). In vitro growth of Oncidium baueri (Orchidaceae) at different macronutrients and sucrose concentrations. .Ciencias Agrarias. 29(4): 775-782.

Stancato, G.C.,Faria, R.T. (1996). In vitro growth and mineral nutrition of the lithophytic orchid Laelia cinnabarina Batem (Orchidaceae). Effects of macro and microelements. Lindleyana, Palm Beach, 11(1):41-43.
Suárez , J.P. Weib. M. Abele. A. Garnica. S. Oberwinkler. F. \& Kottke, I. (2006). Diverse tulasnelloid fungi form mycorrhizas with epiphytic orchids in an Andean cloud forest. Mycol Res. 110, 1257 - 1270. Doi: 10.1016/j.mycres. 2006.08.004.

Valadares, R.B.S. Perotto. S. Santos, E.C. \& Lambais, M.R. (2013). Proteome changes in Oncidium sphacelathum (Orchidaceae), at different trophic stages of symbiotic germination. Mycorrhiza, 24(5),349360.Doi:10.1007/s00572-013-0547-2.

Zepeda, Q.V.H. (2003). Micropropagación de la orquídea Galeandra batemanii Rolfe, una especie amenazada (Tesis de Licenciatura). Universidad Autónoma de Nayarit, Facultad de Agricultura. Xalisco, Nayarit, México. 1-80 pp. 